\title{
Two fatty acid anion-based ionic liquids - part II: Effectiveness as an additive to a polyol ester
}

3

\author{
M. Sernagliaa ${ }^{\mathrm{a}}$ D. Blanco ${ }^{\mathrm{b}}$, A. Hernández Battez ${ }^{\mathrm{b}, \mathrm{c}}$ \\ R. González ${ }^{\mathrm{a}, \mathrm{c}}$, A. Fernández-González ${ }^{\mathrm{d}}, \mathrm{M}$. Bartoloméa
}

\begin{abstract}
This work is about the use of two ionic liquids obtained from fatty acids (FAILs) as an additive at 0.5 and $2 \mathrm{wt}$ \% to a polyol ester (POE) base oil. Tribological tests under two different configurations (reciprocating and sliding/rolling "ball-on-disc") were performed at different temperatures and loads. Worn surface was measured and analyzed after reciprocating experiments by confocal and scanning electron microscopies and by X-ray photoelectron spectroscopy (XPS). Main results showed that these FAILs at low concentration did not change the viscosity of the POE and hence the tribological behaviors of the mixtures and the POE under elastohydrodynamic lubrication (EHL) in rolling/sliding tests were similar, but using mixtures resulted in lower friction regarding the POE under mixed lubrication regime; the friction behavior in reciprocating tests was similar with the use of all mixtures and the POE at $25^{\circ} \mathrm{C}$ for the two loads used, while the mixtures outperformed the antiwear behavior of the POE; the antifriction behavior of the mixtures under both loads at $100{ }^{\circ} \mathrm{C}$ was slightly worse than that of the POE and all mixtures had better antiwear performance than the POE.
\end{abstract}

Keywords: ionic liquids; additive; polyol ester base oil; lubrication; friction; wear

\section{Introduction}

In the early years of the twenty century, the ethylammonium nitrate $\left[\left(\mathrm{C}_{2} \mathrm{H}_{5}\right) \mathrm{NH}_{3}\right]\left[\mathrm{NO}_{3}\right]$ was reported as the first ionic liquid (IL) [1]. The research interest of these liquid salts, which melt at temperatures lower than $100{ }^{\circ} \mathrm{C}$, started to grow in the 70 s using pyridinium/imidazolium cations and halide/tetrahalogenoaluminate anions for synthetizing ILs and employ them as electrolytes in batteries [2,3]. The first known drawback of ILs was the possible basicity or acidity of these novel substances, which could represent a problem in many applications. This issue was solved in the 90s when Wilkes and Zawarotko [4] obtained new ILs formed by neutral weakly coordinating anions, such as tetrafluoroborate $\left[\mathrm{BF}_{4}\right]^{-}$and hexafluorophosphate $\left[\mathrm{PF}_{6}\right]^{-}$. These new ILs allowed a significant growth of research in numerous industrial applications: catalysts, liquid crystals, extraction technology, solvents for both organic or inorganic materials and synthesis [5-8].

The findings of the promising lubricant behaviour of ILs was firstly reported in 2001 [9]. This lubricant property is related to some interesting features of these novel salts: non-volatility, high thermo-oxidative stability and wide liquid range. Along the next 10 years, numerous journal papers and patents about tribological application of ILs have been published, demonstrating the huge interest on this topic [10-21]. 
1 The possibility of using these novel substances in lubricant formulation is mainly related to their capacity

2 to form tribofilms on the contact surface, resulting in both antifriction and antiwear improvements [22-26].

3 Despite all these advantages of the ILs, two major problems appeared regarding the use of ILs in lubrication.

4 Although these substances were firstly considered as green lubricants, the majority of ILs contain elements

5 that are toxic or hazardous to the environment [27-31]. In addition, the price of these substances remains

6 too high, so the use of ILs as neat lubricants are limited to very specific applications [32-35]. This above-

7 mentioned fact causes that the use of ILs as lubricant additive is for now more reasonable than using them

8 as base fluid or pure lubricant [36-44]. However, the inherent polarity of ILs provoked that a lot of

9 researches using ILs as additive have been carried out over the last two decades in order to overcome the

10 solubility issue. The first research works using non-polar hydrocarbon oils as lubricant base stock were

11 very low IL-concentrations mixtures or even oil-IL emulsions that need to be stabilized [45-49]. This

12 approach could take advantage of aditising non-polar oils with low-concentration polar additive [50-52].

13 Taking into account the solubility problem in non-polar base oils, the ILs were generally found having 14 better compatibility with polar oils [53-59].

15 The toxicity problem of the ILs have been addressed throughout selecting proper constituent ions for 16 searching of new environmentally friendly compounds that contribute to a more sustainable development $17[60,61]$. According to this purpose, not only bio-based lubricants and additives [62-66], but also FAILs are being studied. The synthesis of FAILs via metathesis reaction was firstly reported in 2013 [67]. From that moment, the research works focused on using these novel compounds in lubrication increased exponentially in recent years [68-82].

21 Two novel FAILs (tetrahexylammonium octanoate, $\left[\mathrm{N}_{6,6,6,6}\right]\left[\mathrm{C}_{8: 0}\right]$, and tetrahexylammonium palmitate,

$\left.22\left[\mathrm{~N}_{6,6,6,6}\right]\left[\mathrm{C}_{16: 0}\right]\right)$ were studied as neat lubricant in the first part of this work [83]. Now, this paper addresses the use of them as an additive to a polyol ester with the goal of assessing their tribological performance.

\section{Methodology}

\subsection{Fatty Acid anion-based Ionic Liquids (FAILs)}

28 The tetrahexylammonium octanoate $\left[\mathrm{N}_{6,6,6,6}\right]\left[\mathrm{C}_{8: 0}\right]$ and tetrahexylammonium palmitate $\left[\mathrm{N}_{6,6,6,6}\right]\left[\mathrm{C}_{16: 0}\right]$ fatty 29 acid anion-based ionic liquids (FAILs) were synthetized using caprylic acid (octanoic) for the former and 30 palmitic acid (hexadecenoic) for the latter as anionic precursor (water content of both FAILs: $<2$ wt.\%). In 31 addition, tetrahexylammonium bromide was employed as cationic precursor and acquired from Sigma- 
1 Aldrich S.A. The process of synthesis was performed through a double replacement reaction. Besides, ${ }^{1} \mathrm{H}$

2 and ${ }^{13} \mathrm{C}$ nuclear magnetic resonance (NMR) and FTIR spectroscopy were executed to ascertain the chemical

3 structure. The synthesis/identification procedure of these FAILs were described extensively in the first part

4 of this research, as well as their density and viscosity data [83].

\section{$6 \quad 2.2$ Preparation of mixtures}

7 With the aim of analysing the miscibility of the two studied FAILs in different commercial oils, 5 wt.\% samples were prepared using three different base oils kindly supplied by REPSOL: a Group IV synthetic base oil (PAO 4), a Group I mineral base oil (SN-150) and a Group V polyol ester base oil (Priolube 3970). Density and viscosity at reference temperatures of these base oils are reported as Supplementary Information. A simple experiment was conducted looking for the most appropriate base oil from a miscibility point of view: all 6 blends (each FAIL at 5 wt.\% in the three base oils) were mixed manually. The progress of the mixtures' stability was followed by visual inspection along $48 \mathrm{~h}$ and only the mixtures with the polyol ester (POE) were miscible, while the others showed two immiscible phases. Finally, FAILs were separately mixed at two different concentrations $(0.5$ and 2 wt.\%) in the POE using an ultrasonic probe (Bandelin Sonoplus HD2200) at 70\% of amplitude for $5 \mathrm{~min}$ and controlling the blend temperature below $60^{\circ} \mathrm{C}$.

\subsection{Density and viscosity}

The density and dynamic viscosity of the blends were obtained according to ASTM D7042 between 20 and $100{ }^{\circ} \mathrm{C}$ (atmospheric pressure), taking measurements every $10{ }^{\circ} \mathrm{C}$ in a Couette rotational viscometer (SVM 3001 Stabinger Viscometer). The equipment automatically calculates the kinematic viscosity and the viscosity index according to the ASTM D445 and ASTM D2270 standards, respectively.

\subsection{Friction and wear tests}

26 Two different tribometers were used in order to characterize the tribological behaviour of the FAILcontaining samples. The PCS Instruments Mini-Traction Machine (MTM) with a ball-on-disc setup was employed for performing a test at $50 \%$ of slide-to-roll ratio (SRR) and varying the mean entrainment speed in the $2500-10 \mathrm{~mm} / \mathrm{s}$ range (using decreasing steps of $100 \mathrm{~mm} / \mathrm{s}$ until reaching a speed of $100 \mathrm{~mm} / \mathrm{s}$ and at $10 \mathrm{~mm} / \mathrm{s}$ steps from a speed of $100 \mathrm{~mm} / \mathrm{s}$ until $10 \mathrm{~mm} / \mathrm{s}$ ) while electrical contact resistance (ECR) and 
1 friction coefficient were recorded. A lubricant volume of $10 \mathrm{~mL}, 30 \mathrm{~N}-$ load $(0.95 \mathrm{GPa}$ of maximum contact 2 pressure) and $40,60,80$ and $100{ }^{\circ} \mathrm{C}$ of temperature were used in this test. Before the test, both MTM 3 specimens (discs and balls) were cleaned with petroleum ether for 20 min using an ultrasonic bath, then 4 rinsed in ethanol and finally dried with air. The lower specimen is a disc of AISI 52100 steel with 720-780 $5 \mathrm{HV}_{30}$ of hardness and surface roughness $(\mathrm{Ra}<0.02 \mu \mathrm{m})$. The upper specimen is a ball of AISI 52100 steel 6 with hardness of $800-920 \mathrm{HV}_{30}$ and $\mathrm{Ra}<0.02 \mu \mathrm{m}$ of surface roughness.

7 In addition, a Bruker UMT-3 tribometer with a ball-on-plate reciprocating configuration was also used for 8 measuring the lubricant properties of the mixtures. These tests were conducted during $30 \mathrm{~min}$, loads of 30 and $50 \mathrm{~N}$ (2.06 and $2.43 \mathrm{GPa}$ of maximum contact pressures, respectively), frequency of $15 \mathrm{~Hz}$, stroke length of $4 \mathrm{~mm}, 4 \mathrm{~mL}$ of sample volume and temperatures of 25 and $100{ }^{\circ} \mathrm{C}$. At least 3 replicates for every test condition were made involving a relative error less than $10 \%$. An ultrasonic bath was used for cleaning the specimens with petroleum ether during $25 \mathrm{~min}$, then rinsed in ethanol and finally dried with air before and after the tests. In this case, the lower specimen was a disc of AISI 52100 steel with $225 \mathrm{HV}_{30}$ of hardness and $\mathrm{Ra}=0.018 \mu \mathrm{m}$ of surface roughness, and the upper specimen was a ball of AISI 52100 steel (58-66 HRC of hardness, $\mathrm{Ra}=0.05 \mu \mathrm{m}$ of surface roughness).

\subsection{Surface characterization}

All lower specimens (discs) employed in the tribological tests performed with the UMT-3 were studied by confocal microscopy. This equipment can capture multiple two-dimensional images at different depths in the sample enabling the reconstruction of a three-dimensional wear scar topography and calculating its volume from a selected reference plane. In addition, different techniques such as: scanning electron microscopy (SEM) and both energy dispersive and X-ray photoelectron spectroscopies (EDS-XPS) were employed in order to evaluate the chemical interaction between the surface and the lubricant samples.

24 A JSM-5600LV SEM (JEOL) device operating in low vacuum (LV) with imaging mode detection of secondary and backscattered electrons was employed. The equipment was also fitted with an energy dispersive X-ray microanalysis (EDX) Oxford Inca Energy 200 apparatus allowing elementary mapping of the sample and qualitative-quantitative structural determination for elements between $\mathrm{Be}$ and $\mathrm{U}$ thanks to its X-ray based characterization capabilities. The SEM microscope was set to work at $20 \mathrm{kV}$ voltage and images were taken at x100 magnification. 
1 XPS tests were carried out with a SPECS spectrometer. A $K_{\alpha}(\mathrm{Al})$ monochromatized X-ray source at $45^{\circ}$

$2 \quad(1486.7 \mathrm{eV})$ was employed for the experiments. The final X-ray spot (area of $3.5 \times 1 \mathrm{~mm}^{2}$ ) was always

3 focused on the wear scar. In addition, binding energy was corrected using the position of the adventituos

4 carbon $(284.6 \mathrm{eV})$. At least 0 scans were taken for every analysis (step energy of $0.1 \mathrm{eV}$ and pass energy

$530 \mathrm{eV}$ ). The total number of scans depended on each sample and element.

6

7

8

9

\section{Results and discussion}

\subsection{Density and viscosity}

These properties were measured in the first part of this research [83], exhibiting the same behavior that other FAILs employed in previous research [84-87]. In addition, Table 1 shows density and viscosity values at reference temperatures (additional data can be found as Supplementary Information) of the blends resulting of mixing the FAILs at 0.5 and $2 \%$ in POE. In view of the results, it can be concluded that the use of ionic liquids at the concentrations employed in this research study hardly change some initial base oil properties, such as density, viscosity and viscosity index.

Table 1. Density and viscosity parameters of the FAIL-containing mixtures.

\subsection{Tribological properties}

Fig. 1 shows both friction and ECR performance from tests lubricated with the POE under sliding/rolling conditions $(\mathrm{SRR}=50 \%)$ at different speeds and temperatures. The test performed under EHL regime in the $2500-1000 \mathrm{~mm} / \mathrm{s}$ range at all temperatures with decreasing friction at increasing temperature. This friction behavior takes place because of viscosity control friction under EHL regime and viscosity decrease with temperature. The thicker lubricant film under this lubrication regime results in higher ECR values. From a speed of $1000 \mathrm{~mm} / \mathrm{s}$ downwards, the lubrication regime changed from elastohydrodynamic to mixed corresponding to a decrease in ECR due to a thinner lubricant film. 


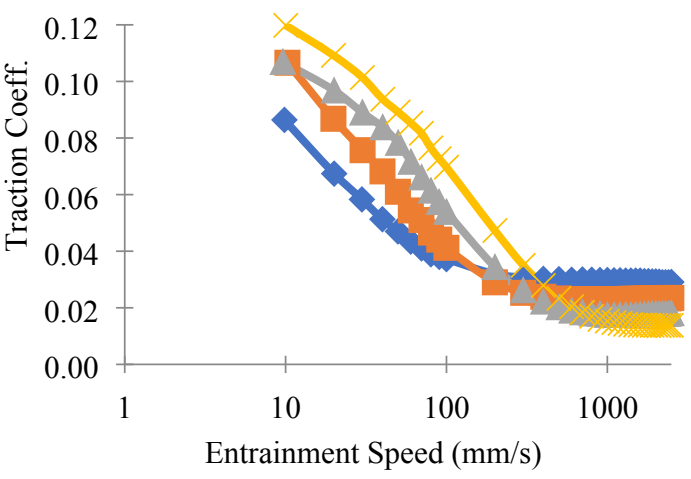

$\longrightarrow 40^{\circ} \mathrm{C}-60^{\circ} \mathrm{C} \longrightarrow 80^{\circ} \mathrm{C} \longrightarrow 100^{\circ} \mathrm{C}$

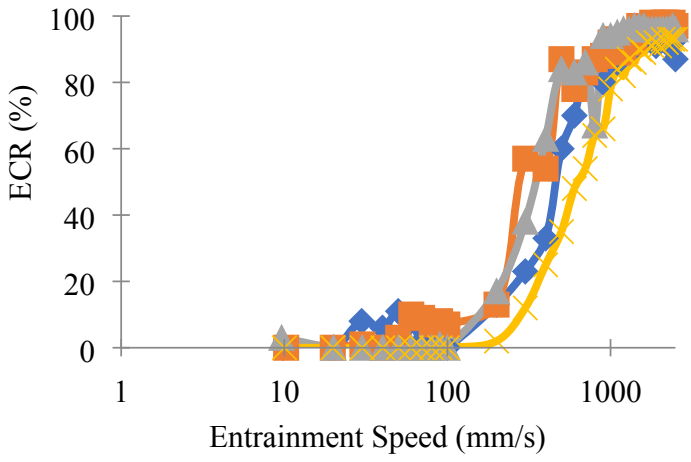

$\longrightarrow 40^{\circ} \mathrm{C}-60^{\circ} \mathrm{C} \longrightarrow 80^{\circ} \mathrm{C} \longrightarrow 100^{\circ} \mathrm{C}$

Fig. 1 Traction coefficient and electrical contact resistance (ECR) behavior versus speed at different temperatures for the base oil (polyol ester).

\section{The addition of these FAILs to the POE in the concentrations used hardly changed the friction behavior of} the POE (Figs. 2-3) under elastohydrodynamic lubrication regime (see also the Supplementary Information) and the speeds at which the lubrication regime changed from elastohydrodynamic to mixed. These results can be associated with the similar viscosity values of the mixtures and POE (Table 1). Under mixed lubrication regime, as expected, the test made at higher temperature showed the higher friction values according to the lower viscosity, which result in thinner lubricant films (see ECR values in this case) and hence much more asperities contact. However, the additisation with the ionic liquids decreased friction values with regard to the base oil at decreasing speeds (under mixed lubrication regime) in most of the cases as can be observed in the Supplementary Information. 

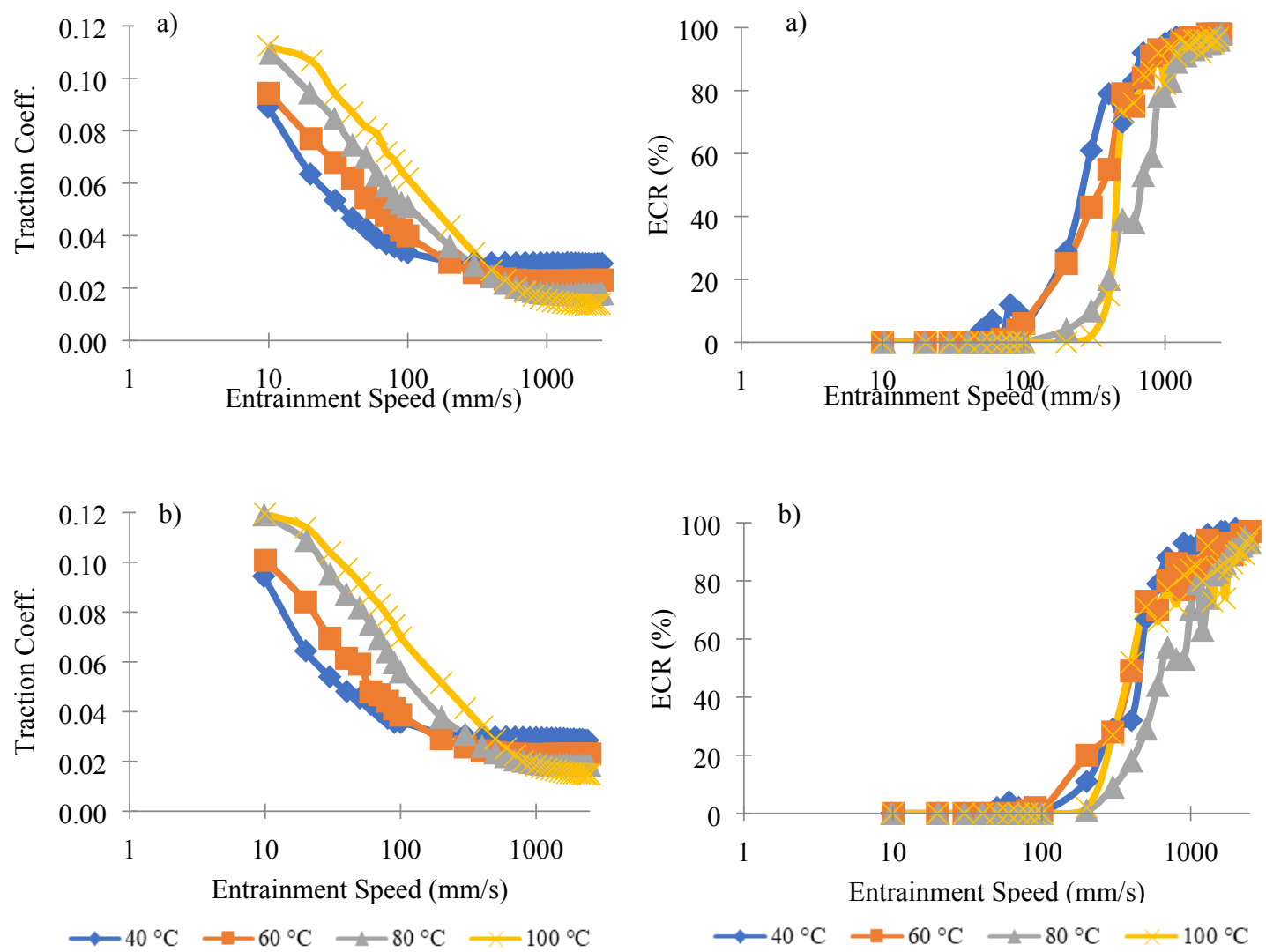

Fig. 2 Traction coefficient and ECR behavior versus speed for: a) POE $+0.5 \%\left[\mathrm{~N}_{6,6,6,6,6}\right]\left[\mathrm{C}_{8: 0}\right]$ and b) $\mathrm{POE}+2 \%\left[\mathrm{~N}_{6,6,6,6}\right]\left[\mathrm{C}_{8: 0}\right]$. 

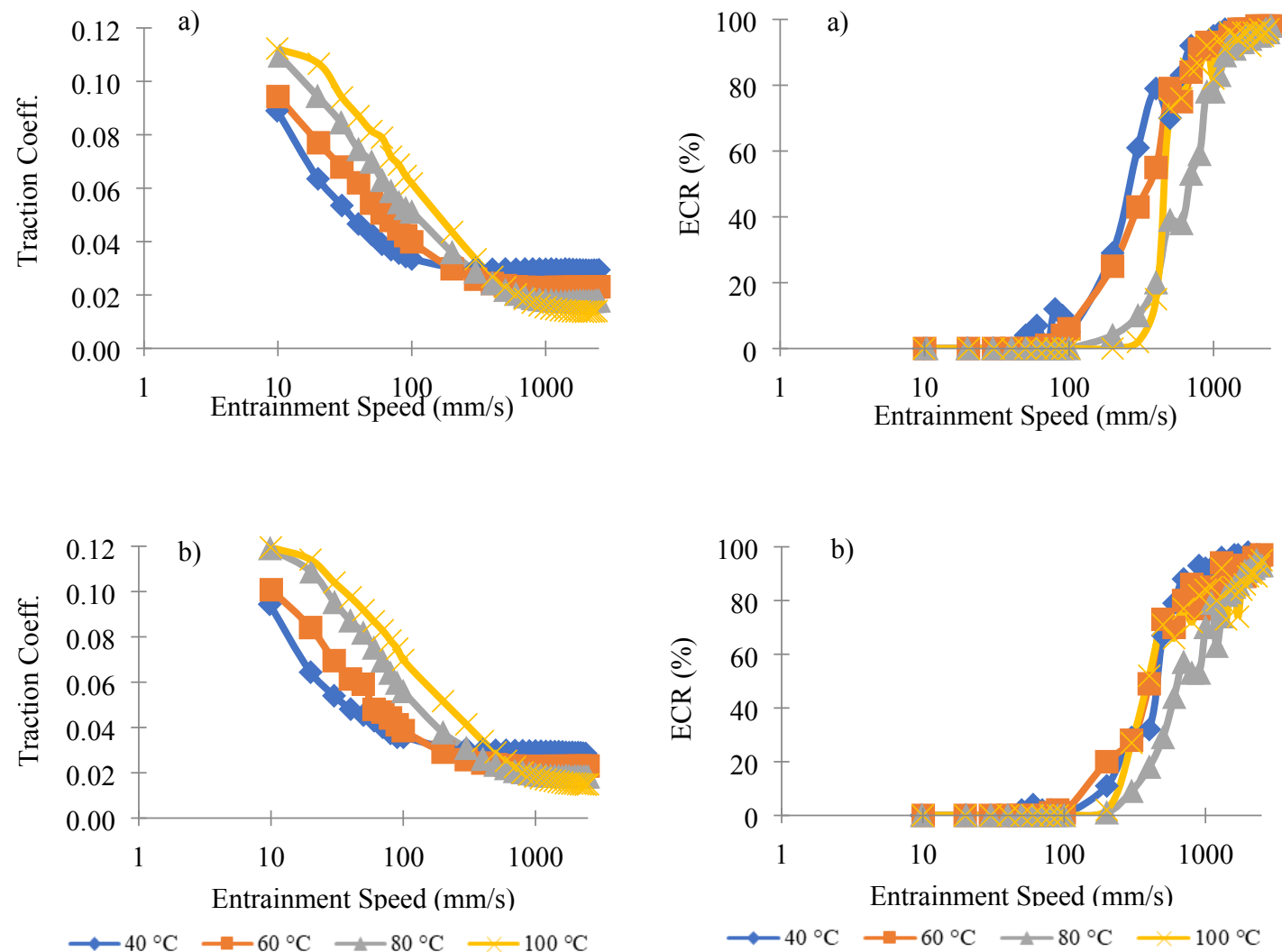

Fig. 3 Traction coefficient and ECR behavior versus speed for: a) $\mathrm{POE}+0.5 \%\left[\mathrm{~N}_{6,6,6,6,6}\right]\left[\mathrm{C}_{16: 0}\right]$ and

b) $\mathrm{POE}+2 \%\left[\mathrm{~N}_{6,6,6,6}\right]\left[\mathrm{C}_{16: 0}\right]$. 
The results from tests made under reciprocating ball-on-disc configuration at $25^{\circ} \mathrm{C}$ shows that mean friction coefficient is quite similar for both loads in the tests performed with mixtures and pure POE, Fig. 4.

However, wear increased with load and the mixtures outperformed the antiwear behavior of POE. The antiwear behavior of all mixtures was quite similar at $30 \mathrm{~N}$-load, meanwhile the $\left[\mathrm{N}_{6,6,6,6}\right]\left[\mathrm{C}_{8: 0}\right]$-containing mixtures outperformed the antiwear behavior of the $\left[\mathrm{N}_{6,6,6,6}\right]\left[\mathrm{C}_{16: 0}\right]$ counterparts at $50 \mathrm{~N}$.
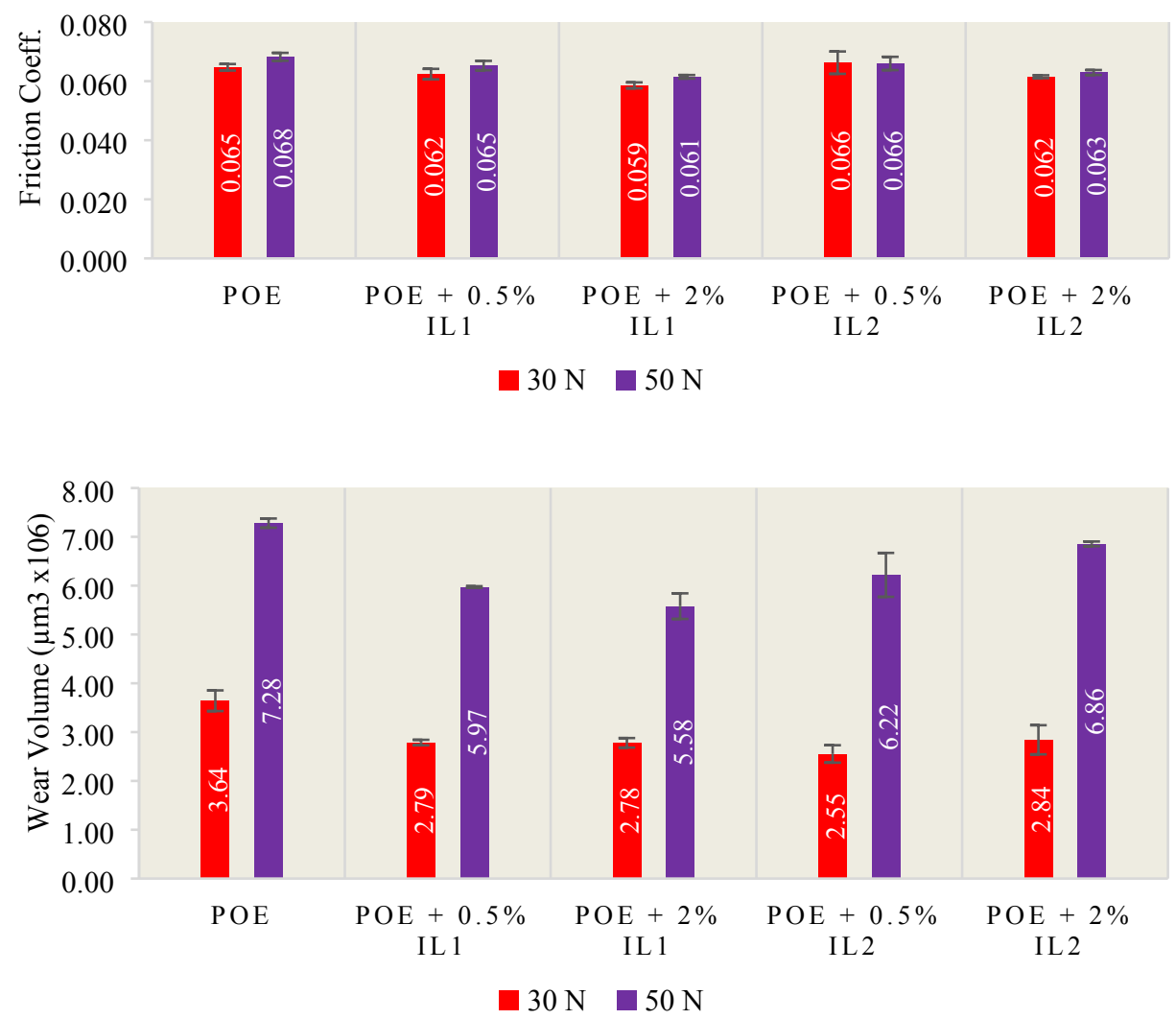

Fig. 4 Friction coefficient and wear volume from tests at $25^{\circ} \mathrm{C}$ (IL1: $\left[\mathrm{N}_{6,6,6,6}\right]\left[\mathrm{C}_{8: 0}\right]$, IL2: $\left.\left[\mathrm{N}_{6,6,6,6}\right]\left[\mathrm{C}_{16: 0}\right]\right)$.

For reciprocating tests at $100{ }^{\circ} \mathrm{C}$, the antifriction behavior of the blends was sligthly worse than that of the base oil, Fig. 5. Analogously to tests performed at $25^{\circ} \mathrm{C}$, the antiwear behavior of the blends was better than that of POE and wear increased with load. All mixtures had similar wear reduction properties at $30 \mathrm{~N}$ load; but the best antiwear behavior at $50 \mathrm{~N}$-load was found for mixture with $0.5 \%$ of $\left[\mathrm{N}_{6,6,6,6}\right]\left[\mathrm{C}_{8: 0}\right]$. This antiwear behavior of the FAILs as an additive at 25 and $100{ }^{\circ} \mathrm{C}$-tests was very similar to that found in the tests performed for these ionic liquids used as neat lubricant at the same temperatures [83]. 


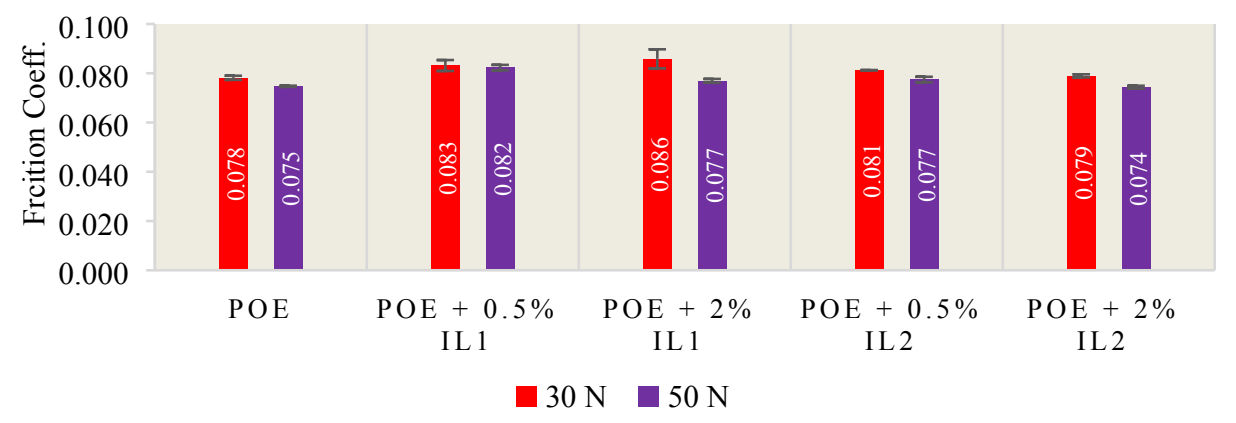

1

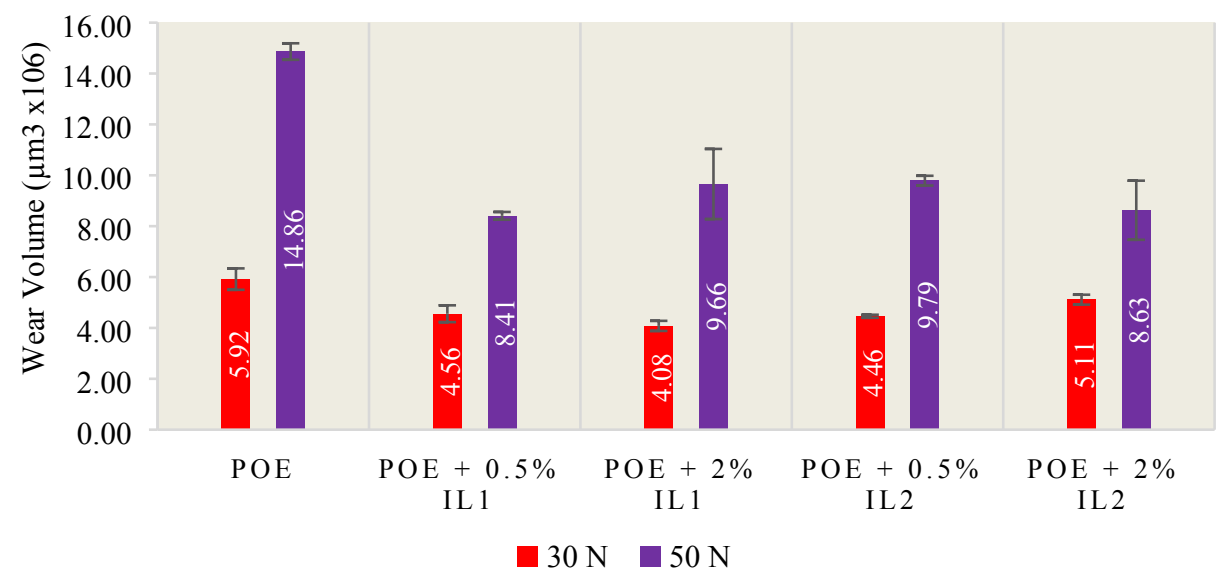

Fig. 5 Friction coefficient and wear volume from tests at $100^{\circ} \mathrm{C}$ (IL1: $\left[\mathrm{N}_{6,6,6,6,6}\right]\left[\mathrm{C}_{8: 0}\right]$, IL2: $\left.\left[\mathrm{N}_{6,6,6,6}\right]\left[\mathrm{C}_{16: 0}\right]\right)$.

6 3.3. Surface characterization

7 The wear scar on the discs after reciprocating tests was studied by SEM and they showed that the

8 predominant wear mechanism was mainly adhesive with plastic deformation (Figs. 6-10). As expected,

9 wear increased with load and temperature. Taking into account the state of the worn surface, it seems that

10 the $\left[\mathrm{N}_{6,6,6,6}\right]\left[\mathrm{C}_{16: 0}\right]$ behaves better at high temperature and load, maybe because its better thermal stability.

11

12

13

14

15

16

17

18

19

20 


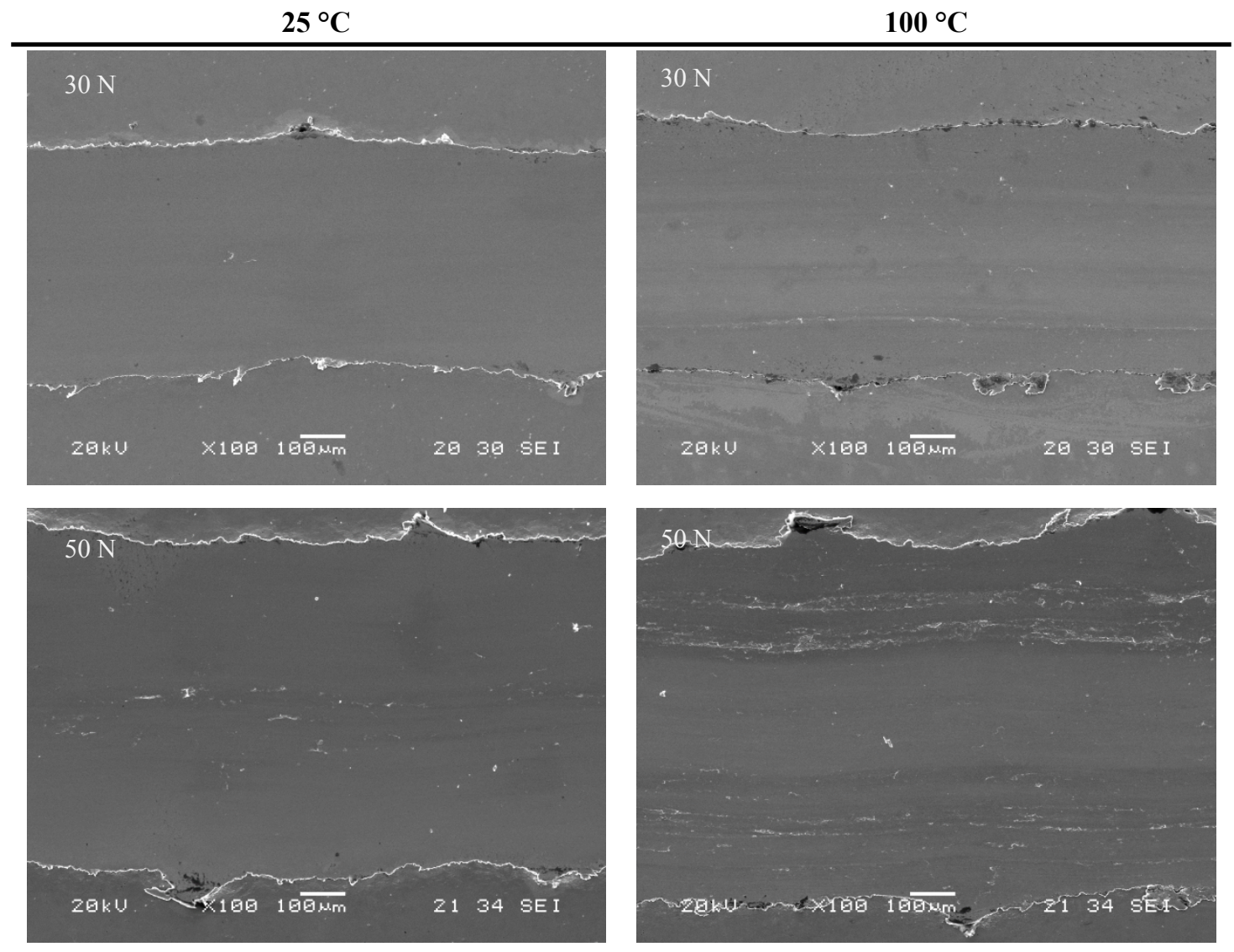

1

Fig. 6 SEM images of the wear track on the disc after tribological tests with pure POE at 30 and $50 \mathrm{~N}$.

2

3

4

5

6

7

8

9

10

11

12 

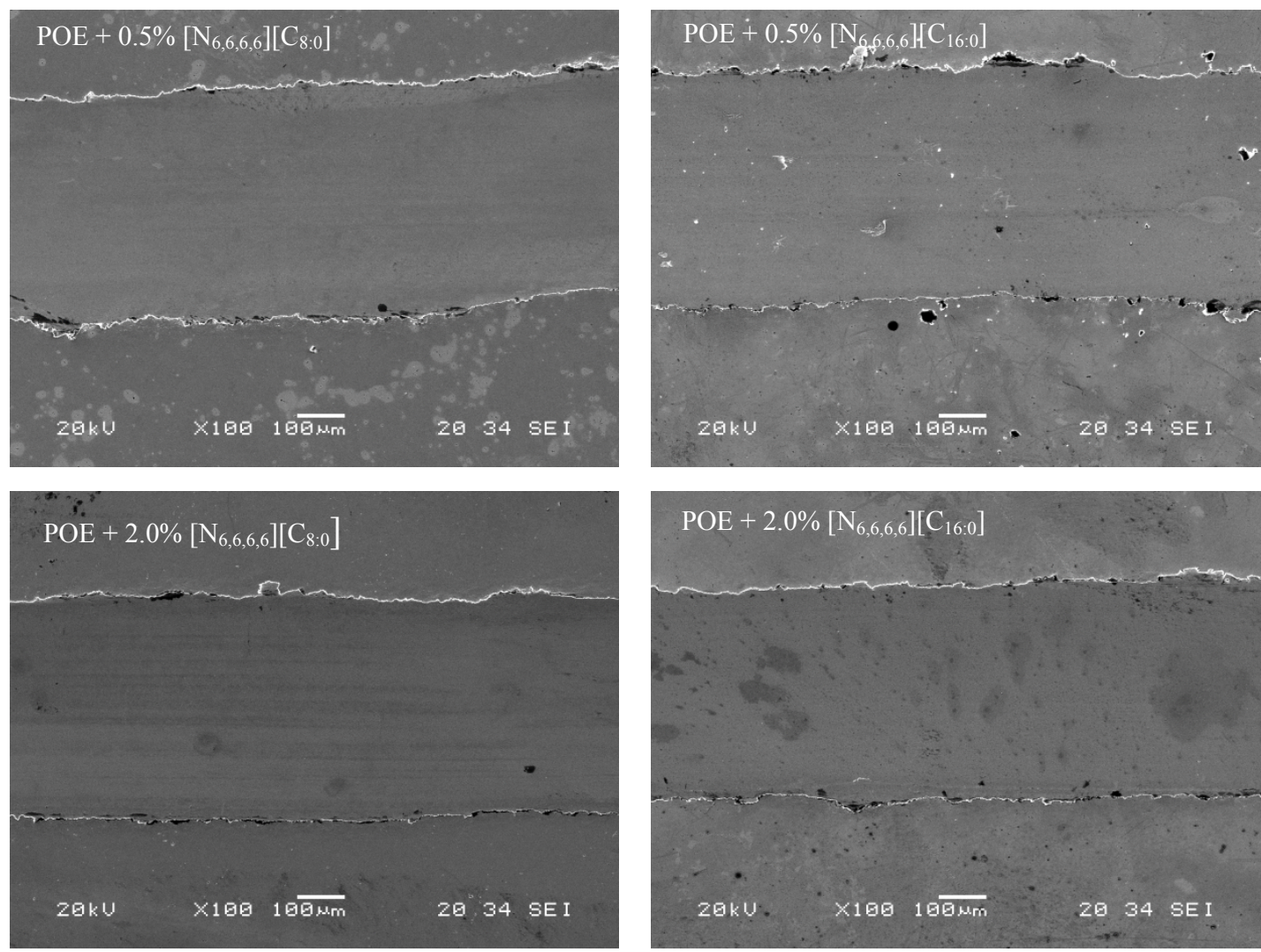

Fig. 7 SEM images of the wear track on the disc after tests with $\left[\mathrm{N}_{6,6,6,6}\right]\left[\mathrm{C}_{8: 0}\right]-$ and $\left[\mathrm{N}_{6,6,6,6,6}\right]\left[\mathrm{C}_{16: 0}\right]$ containing mixtures at $25^{\circ} \mathrm{C}$ and $30 \mathrm{~N}$.

5

6

7

8

9

10

11

12

13

14

15 

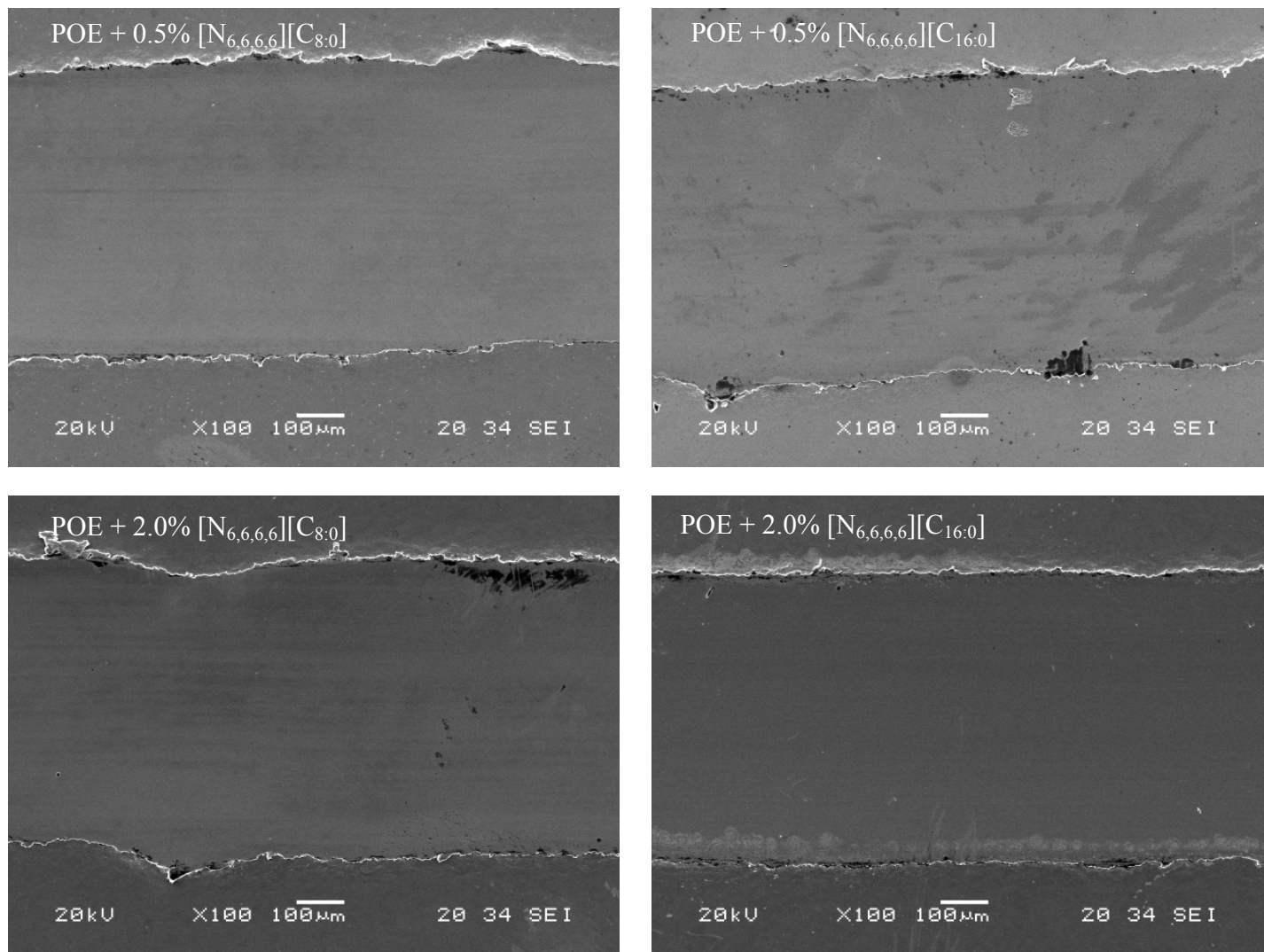

2

Fig. 8 SEM images of the wear track on the disc after tribological with $\left[\mathrm{N}_{6,6,6,6}\right]\left[\mathrm{C}_{8: 0}\right]-$ and $\left[\mathrm{N}_{6,6,6,6}\right]\left[\mathrm{C}_{16: 0}\right]$ containing mixtures at $25^{\circ} \mathrm{C}$ and $50 \mathrm{~N}$. 

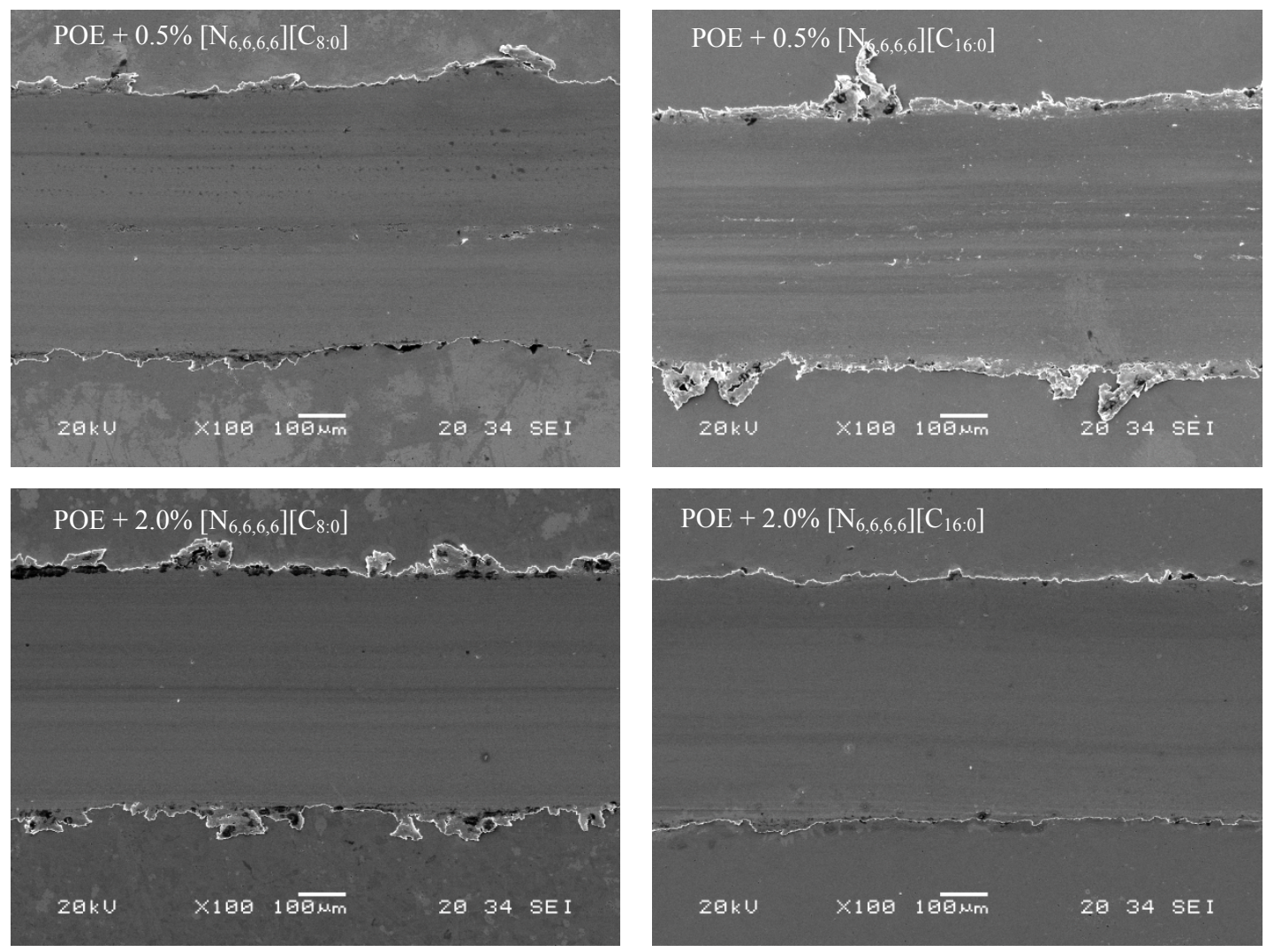

Fig. 9 SEM images of the wear track on the disc after tribological tests with $\left[\mathrm{N}_{6,6,6,6}\right]\left[\mathrm{C}_{8: 0}\right]$ - and $\left[\mathrm{N}_{6,6,6,6}\right]\left[\mathrm{C}_{16: 0}\right]$-containing mixtures at $100^{\circ} \mathrm{C}$ and $30 \mathrm{~N}$. 

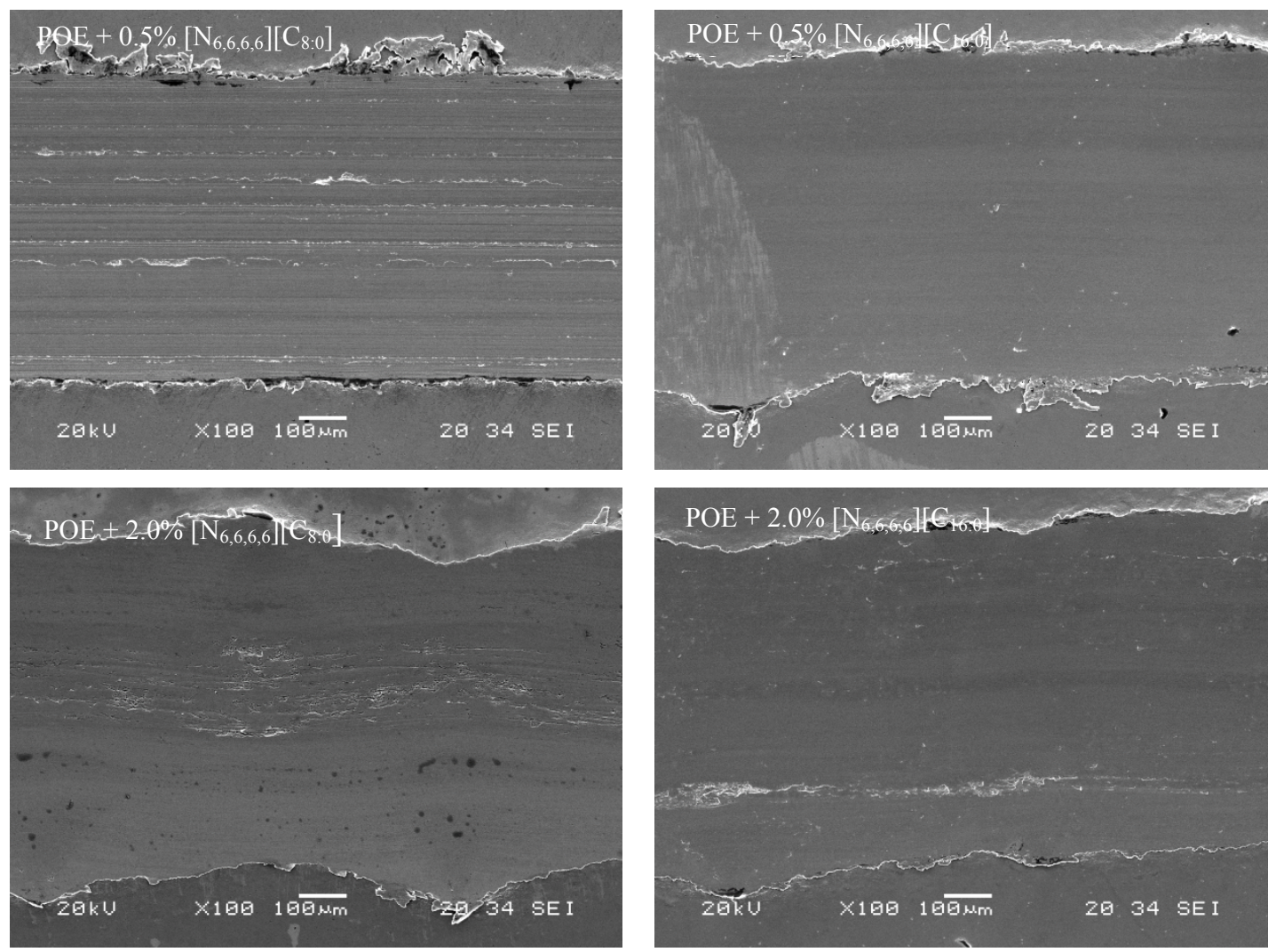

Fig. 10 SEM images of the wear track on the disc after tribological tests with $\left[\mathrm{N}_{6,6,6,6}\right]\left[\mathrm{C}_{8: 0}\right]$ - and $\left[\mathrm{N}_{6,6,6,6}\right]\left[\mathrm{C}_{16: 0}\right]$-containing mixtures at $100^{\circ} \mathrm{C}$ and $50 \mathrm{~N}$.

For clarifying the tribological performance of these FAILs as an additive to a polyol ester at high temperature (more probable scenario in a real application), the worn surface of the discs from some tests were analyzed by XPS. Curve fitting for Fe2p $\mathrm{p}^{3 / 2}$ (Table 2) shows four different peaks, which can be assigned

to $\mathrm{Fe}(0)$ (Gaussian-Lorentzian 70:30 with an exponential blend tail $\mathrm{k}=0.65$ ), $\mathrm{FeO}$ (Gaussian-Lorentzian 70:30), $\mathrm{Fe}_{2} \mathrm{O}_{3}$ (Gaussian-Lorentzian 70:30 with an exponential blend tail k=1.5) and $\mathrm{FeOOH}$ (GaussianLorentzian 70:30) $[56,88,89]$. Samples with the lowest wear volume (those tested at $30 \mathrm{~N}$ ) showed very low amounts of $\mathrm{Fe}(0)$ on the wear track. Steel surface is more accessible to air oxygen than the inner part of the sample and, therefore, it is more likely to find $\mathrm{Fe}(0)$ in the inner layers and oxidized $\mathrm{Fe}$ in the more surface layers. This becomes evident when analyzing the iron composition on the wear track in tests at 30

$14 \mathrm{~N}$ and $50 \mathrm{~N}$. The ones tested with the lowest load showed less damage and, therefore, the $\mathrm{Fe}(0)$ inner layers are not yet reached and only iron oxides can be found. However, the higher wear damage obtained in tests at $50 \mathrm{~N}$ led to reach the $\mathrm{Fe}(0)$ layers below the surface. 
Table 2. XPS bands of the Fe2p $\mathrm{p}^{3 / 2}$ (Temp.: $100^{\circ} \mathrm{C}$ ).

\begin{tabular}{|c|c|c|c|c|c|c|c|c|}
\hline \multirow{3}{*}{ Lubricant samples } & \multicolumn{8}{|c|}{ Load: $50 \mathrm{~N}$} \\
\hline & \multicolumn{4}{|c|}{ Peak position $(\mathrm{eV})$} & \multicolumn{4}{|c|}{ Peak contribution (\%) } \\
\hline & $\mathrm{Fe}(0)$ & $\mathrm{FeO}$ & $\mathrm{Fe}(\mathrm{III})$ & $\mathrm{FeOOH}$ & $\mathrm{Fe}(0)$ & $\mathrm{FeO}$ & $\mathrm{Fe}(\mathrm{III})$ & $\mathrm{FeOOH}$ \\
\hline POE & 706.6 & 709.5 & 711.2 & 713.7 & 21 & 33 & 38 & 8 \\
\hline $\mathrm{POE}+0.5 \%\left[\mathrm{~N}_{6,6,6,6}\right]\left[\mathrm{C}_{8: 0}\right]$ & 707.1 & 709.9 & 710.8 & 713.8 & 21 & 19 & 51 & 10 \\
\hline $\mathrm{POE}+0.5 \%\left[\mathrm{~N}_{6,6,6,6}\right]\left[\mathrm{C}_{16: 0}\right]$ & 707.0 & 709.8 & 710.4 & 713.4 & 22 & 1 & 65 & 12 \\
\hline $\mathrm{POE}+2.0 \%\left[\mathrm{~N}_{6,6,6,6}\right]\left[\mathrm{C}_{8: 0}\right]$ & 707.0 & 710.0 & 710.5 & 714.1 & 19 & 3 & 69 & 9 \\
\hline \multirow[t]{2}{*}{$\mathrm{POE}+2.0 \%\left[\mathrm{~N}_{6,6,6,6,6}\right]\left[\mathrm{C}_{16: 0}\right]$} & 706.9 & - & 709.7 & 712.4 & 21 & - & 63 & 15 \\
\hline & \multicolumn{8}{|c|}{ Load: $30 \mathrm{~N}$} \\
\hline \multirow{2}{*}{ Lubricant samples } & \multicolumn{4}{|c|}{ Peak position $(\mathrm{eV})$} & \multicolumn{4}{|c|}{ Peak contribution (\%) } \\
\hline & $\mathrm{Fe}(0)$ & $\mathrm{FeO}$ & $\mathrm{Fe}(\mathrm{III})$ & $\mathrm{FeOOH}$ & $\mathrm{Fe}(0)$ & $\mathrm{FeO}$ & $\mathrm{Fe}(\mathrm{III})$ & $\mathrm{FeOOH}$ \\
\hline POE & 704.3 & 707.2 & 709.6 & 711.4 & 4 & 15 & 60 & 21 \\
\hline $\mathrm{POE}+0.5 \%\left[\mathrm{~N}_{6,6,6,6}\right]\left[\mathrm{C}_{8: 0}\right]$ & - & 707.2 & 710.0 & 711.9 & - & 11 & 73 & 16 \\
\hline $\mathrm{POE}+0.5 \%\left[\mathrm{~N}_{6,6,6,6}\right]\left[\mathrm{C}_{16: 0}\right]$ & 703.3 & 706.7 & 709.3 & 711.2 & 2 & 14 & 68 & 16 \\
\hline
\end{tabular}

2

3

4

\section{Conclusions}

5 Two FAILs were studied as an additive to a polyol ester at two concentrations ( 0.5 and $2 \mathrm{wt} \%)$ and the main conclusions obtained are the following:

- The use of these FAILs at low concentration did not change the viscosity of the POE and hence the tribological behaviors of the mixtures and the POE under elastohydrodynamic lubrication in rolling/sliding tests were similar. However, the mixtures showed lower friction values under mixed lubrication regime in most of the cases.

- The friction behavior in reciprocating tests was similar with the use of all mixtures and the POE at $25^{\circ} \mathrm{C}$ for the two loads used, while the mixtures outperformed the antiwear behavior of the POE.

- The antifriction behavior of the mixtures under both loads at $100^{\circ} \mathrm{C}$ in reciprocating tests was sligthly worse than that of the POE and all mixtures had better antiwear performance than the POE. 


\section{1}

\section{Acknowledgements}

The authors thank the Spanish Ministry of Economy and Competitiveness and the Foundation for the Promotion of Applied Scientific Research and Technology in Asturias (FICYT) for supporting this work under the framework of the research projects FAILs_LUBEs (DPI2016-79690-R) and LuSuTec (IDI/2018/000131), respectively.

\section{References}

[1] P. Walden, Molecular Weights and Electrical Conductivity of Several Fused Salts, Bulletin of the Imperial Academy of Sciences (St. Petersburg), 8 (1914) 405-422.

[2] H.L. Chum, V. Koch, L. Miller, R. Osteryoung, Electrochemical Scrutiny of Organometallic Iron Complexes and Hexam- ethylbenzene in a Room Temperature Molten Salt, Journal of the American Chemical Society, 97(11) (1975) 3264-3265. https://doi.org/10.1021/ja00844a081.

[3] J.S. Wilkes, J.A. Levisky, R.A. Wilson, C.L. Hussey, Dialkylimidazolium Chloroaluminate Melts: A New Class of Room- Temperature Ionic Liquids for Electrochemistry, Spectroscopy and Synthesis, Inorganic Chemistry, 21(3) (1982) 1263-1264. https://doi.org/10.1021/ic00133a078.

[4] J.S. Wilkes, M.J. Zaworotko, Air and water stable 1-ethyl-3-methylimidazolium based ionic liquids, Chemical Communications (13) (1992) 965-967. https://doi.org/10.1039/c39920000965.

[5] P. Wassercheid, T. Welton, Ionic liquid in synthesis, Wiley 2nd ed. (2008) Germany.

[6] H. Olivier, Recent developments in the use of non-aqueous ionic liquids for two-phase catalysis, J Mol Catal A. Chem 146 (1999) 285-289. http://dx.doi.org/ 10.1016/S1381-1169(99)00114-4.

[7] R. Hagiwara, Y. Ito, Room temperature ionic liquids of alkylimidazolium cations and fluoroanions, J Fluor Chem 105 (2000) 221-227. http://dx.doi.org/10.1016/ S0022-1139(99)00267-5.

[8] T. Welton, Room-Temperature Ionic Liquids. Solvents for Synthesis and Catalysis, Chemical Reviews, 99(8) (1999) 2071-2084. https://doi.org/10.1021/cr980032t.

[9] C. Ye, W. Liu, Y. Chen, L. Yu, Room-temperature ionic liquids: a novel versatile lubricant, Chem. Commun. (2001) 2244-2245. https://doi.org/10.1039/b106935g.

[10] W. Liu, C. Ye, Q. Gong, H. Wang, P. Wang, Tribological performance of room-temperature ionic liquids as lubricant, Tribol. Lett. 13 (2002) 81-85. https://doi.org/10.1023/A:1020148514877.

[11] R.A. Reich, P.A. Stewart, J. Bohaychick, J.A. Urbanski, Base oil properties of ionic liquids, Lubr. Eng. 59, 7 (2003) 16-21. 
1 [12] H. Wang, Q. Lu, C. Ye, W. Liu, Z. Cui, Friction and wear behaviors of ionic liquid of alkylimidazolium hexafluorophosphates as lubricants for steel/steel contact, Wear 256 (2004) 44-48. http://dx.doi.org/10.1016/S0043-1648(03)00255-2.

[13] Z. Mu, F. Zhou, S. Zhang, Y. Liang, W. Liu, Effect of the functional groups in ionic liquid molecules on the friction and wear behavior of aluminum alloy in lubricated aluminum-on-steel contact, Trib Int 38 (8) (2005) 725-731. https://doi.org/10.1016/j.triboint.2004.10.003.

[14] X. Liu, F. Zhou, Y. Liang, W. Liu, Tribological performance of phosphonium based ionic liquids for an aluminium-on-steel system and opinions on lubrication mechanism, Wear 261 (10) (2006) 11741179. https://doi.org/10.1016/j.wear.2006.03.018.

[15] J. Qu, J.J. Truhan, S. Dai, H. Luo, P.J. Blau, Ionic liquids with ammonium cations as lubricants or additives, Tribol Lett 22 (2006) 207-214. https://doi.org/10.1007/s11249-006-9081-0.

[16] H. Kamimura, T. Kubo, I. Minami, S. Mori, Effect and mechanism of additives for ionic liquids as new lubricants, Trib Int 40 (4) (2007) 620-625. https://doi.org/10.1016/j.triboint.2005.11.009.

[17] M. Fox, M. Priest, Tribological properties of ionic liquids as lubricants and additives. Part 1: synergistic tribofilm formation between ionic liquids and tricresylphosphate, Proc. IMechE Part J: J. Eng. Tribol. 222 (2008) 291-303. https://doi.org/10.1243/13506501JET387.

[18] I. Minami. Ionic liquids in tribology, Molecules 14(6) (2009) 2286-2305. https://doi.org/10.3390/molecules14062286.

[19] M.D. Bermúdez, A.E. Jiménez, J. Sanes, F.J. Carrión, Ionic liquids as advanced lubricant fluids, Molecules 14 (2009) 2888-2908. https://doi.org/10.3390/molecules14082888.

[20] J.V. Rensselar, Unleashing the potential of ionic liquids, Tribol Lubr Technol 4 (2010) 24-31.

[21] D. Blanco, A.H. Battez, J.L. Viesca, R. González, A. Fernández-González, Lubrication of CrN coating with ethyl-dimethyl-2-methoxyethylammonium tris(pentafluoroethyl)trifluorophosphate ionic liquid as additive to PAO 6. Tribology Letters 41(1) (2011) 295-302. https://doi.org/10.1007/s11249-0109714-1.

[22] F. Zhou, Y. Liangm, W. Liu, Ionic liquid lubricants: designed chemistry for engineering applications, Chemical Society Reviews, 38(9) (2009) 2590-2599. https://doi.org/10.1039/b817899m.

[23] K.J. Fraser, D.R. MacFarlane, Phosphonium-based ionic liquids: an overview, Australian Journal of Chemistry, 62(4) (2009) 309-321. https://doi.org/10.1071/CH08558. 
1 [24] A.E. Somers, P.C. Howlett, D.R. MacFarlane, M. Forsyth, (2013), A review of ionic liquid lubricants. Lubricants, 1(1) (2013) 3-21. https://doi.org/10.3390/lubricants1010003.

3 [25] H. Xiao, Ionic liquid lubricants: basics and applications, Tribology Transactions 60(1) (2017) 20-30. https://doi.org/10.1080/10402004.2016.1142629.

[26] A.H. Battez, C.M.C.G. Fernandes, R.C. Martins, B.M. Graça, M. Anand, D. Blanco, J.H.O. Seabra, Two phosphonium cation-based ionic liquids used as lubricant additive. Part II: tribofilm analysis and friction torque loss in cylindrical roller thrust bearings at constant temperature, Tribol. Int., 109 (2017) 496-504. https://doi.org/10.1016/j.triboint.2017.01.020.

[27] S.P.M. Ventura, C.S. Marques, A.A. Rosatella, C.A.M. Afonso, F. Gonçalves, J.A.P. Coutinho, Toxicity assessment of various ionic liquid families towards Vibrio fischeri marine bacteria. Ecotoxicol. Environ. Saf. 76 (2012) 162-168. https://doi:10.1016/j.ecoenv.2011.10.006.

[28] D. Zhao, Y. Liao, Z.D. Zhang, Toxicity of ionic liquids. Clean - Soil, Air, Water 35 (2007) 42-48. https://doi:10.1002/clen.200600015.

[29] J. Salgado, J.J. Parajó, T. Teijeira, O. Cruz, J. Proupín, M. Villanueva, J.A. Rodríguez-Añón, P.V. Verdes, O. Reyes, New insight into the environmental impact of two imidazolium ionic liquids. Effects on seed germination and soil microbial activity, Chemosphere 185 (2017) 665-672. https://doi:10.1016/j.chemosphere.2017.07.065.

[30] O.B. Ghanem, N. Papaiconomou, M.I. Abdul Mutalib, S. Viboud, M. El-Harbawi, Y. Uemura, G. Gonfa, M.A. Bustam, J.M. Leveque, Thermophysical properties and acute toxicity towards green algae and Vibrio fischeri of amino acid-based ionic liquids, J. Mol. Liq. 212 (2015) 352-359. https://doi:10.1016/j.molliq.2015.09.017.

[31] C. Pretti, C. Chiappe, I. Baldetti, S. Brunini, G. Monni, L. Intorre, Acute toxicity of ionic liquids for three freshwater organisms: Pseudokirchneriella subcapitata, Daphnia magna and Danio rerio, Ecotoxicol. Environ. Saf. 72 (2009) 1170-1176. https://doi.org/10.1016/j.ecoenv.2008.09.010.

[32] T. Predel, E. Schluecker, P. Wasserscheid, D. Gerhard, W. Arlt, Ionic liquids as operating fluids in high pressure applications, Chemical Engineering and Technology 30 (2007) 1475-80. https://doi.org/10.1002/ceat.200700276.

[33] Y. Mo, F. Huang, F. Zhao, Functinalized imidazolium wear-resistant ionic liquid ultrathin films for MEMS/NEMS applications, Surface and Interface Analysis 43 (2011) 1006-1014. https://doi.org/10.1002/sia.3684. 
1 [34] J.J. Nainaparampil, K.C. Eapen, J.H. Sanders, A. Voevodin, Ionic-liquid lubrication of sliding MEMS contacts: comparison of AFM liquid cell and device-level tests, J Microelectromech Syst 16 (2007) 836-843. http://dx.doi.org/10.1109/ JMEMS.2007.901628.

[35] K.W. Street Jr., W. Morales, V.R. Koch, D.J. Valco, R.M. Richard, N. Hanks, Evaluation of vapor (2011) 911-919. https://doi.org/10.1080/10402004.2011.606963.

[36] Y. Zhou, J. Qu, Ionic liquids as lubricant additives - a review. ACS Applied Materials and Interfaces, 9(4) (2016) 3209-3222. https://doi.org/10.1021/acsami.6b12489.

[37] J. Sanes, M.D. Avilés, N. Saurín, T. Espinosa, F.J. Carrión, M.D. Bermúdez, Synergy between graphene and ionic liquid lubricant additives. Tribology International, 116(7) (2017) 371-382. https://doi.org/10.1016/j.triboint.2017.07.030.

[38] Y. Wang, Q. Yu, M. Cai, L. Shi, F. Zhou, W. Liu, Ibuprofen-Based Ionic Liquids as Additives for Enhancing the Lubricity and Antiwear of Water-Ethylene Glycol Liquid. Tribology Letters, 65(2) (2017) 1-13. https://doi.org/10.1007/s11249-017-0840-x.

[39] D. Jiang, L. Hu, D. Feng, Tribological properties of crown-type phosphate ionic liquids as lubricating additives in rapeseed oils. Lubrication Science, 25 (2013) 195-207. https://doi.org/10.1002/ls.1199.

[40] G. Huang, Q. Yu, Z. Ma, M. Cai, F. Zhou, W. Liu, Oil-soluble ionic liquids as antiwear and extreme pressure additives in poly- $\alpha$-olefin for steel / steel contacts, Friction, 7(1) (2019) 18-31. https://doi.org/10.1007/s40544-017-0180-8.

[41] A.E. Somers, B. Khemchandani, P.C. Howlett, J. Sun, D.R. Macfarlane, M. Forsyth, Ionic liquids as antiwear additives in base oils: Influence of structure on miscibility and antiwear performance for steel on aluminum, ACS Applied Materials and Interfaces, 5(22) (2013) 11544-11553. https://doi.org/10.1021/am4037614.

[42] D. Blanco, R. González, J.L. Viesca, A. Fernández-González, M. Bartolomé, A. Hernández Battez, Antifriction and Antiwear Properties of an Ionic Liquid with Fluorine-Containing Anion Used as Lubricant Additive, Tribology Letters, 65(2) (2017) 66. https://doi.org/10.1007/s11249-017-0846-4.

[43] R. González, M. Bartolomé, D. Blanco, J.L. Viesca, A. Fernández-González, A.H. Battez, Effectiveness of phosphonium cation-based ionic liquids as lubricant additive, Tribology International, 98 (2016) 82-93. https://doi.org/10.1016/j.triboint.2016.02.016. 
1 [44] A. Hernández Battez, C.M.C.G. Fernandes, R.C. Martins, M. Bartolomé, R. González, J.H.O. Seabra, Two phosphonium cation-based ionic liquids used as lubricant additive: Part I: Film thickness and friction characteristics, Tribology International, 107(11) (2017) 233-239. https://doi.org/10.1016/j.triboint.2016.10.048.

[45] J. Qu, P.J. Blau, S. Dai, H. Luo, H.M. Meyer, Ionic Liquids as Novel Lubricants and Additives for Diesel Engine Applications, Tribol Lett, 35 (2019) 181-189. https://doi.org/10.1007/s11249-0099447-1.

[46] K. Mistry, M.F. Fox, M.J. Priest MJ, Lubrication of an Electroplated Nickel Matrix Silicon Carbide Coated Eutectic Aluminium-Silicon Alloy Automotive CylinderBore with an Ionic Liquid as a Lubricant Additive, Eng Tribol, 223 (2009) 563-569. https://doi.org/10.1243/13506501JET562.

[47] A.H. Battez, R. González, J.L. Viesca, D. Blanco, E. Asedegbega, A. Osorio, Tribological behaviour of two imidazolium ionic liquids as lubricant additives for steel/steel contacts, Wear, 266 (2209) 1224-1228. https://doi.org/10.1016/j.wear.2009.03.043.

[48] R. Lu, H. Nanao, K. Kobayashi, T. Kubo, S. Mori, Effect of Lubricant Additives on Tribochemical Decomposition of Hydrocarbon Oil on Nascent Steel Surfaces, J Jpn Petrol Inst, 53 (2010) 55- 60. https://doi.org/10.1627/jpi.53.55.

[49] J.L. Viesca, M. Anand, D. Blanco, A. Fernández-González, A. García, M. Hadfield, Tribological Behaviour of PVD Coatings Lubricated with a FAP- Anion-Based Ionic Liquid Used as an Additive, Lubricants, 4(1) (2016) 8. https://doi.org/10.3390/lubricants4010008.

[50] G. Guangteng, H. Spikes, Fractionation of liquid lubricants at solid surfaces, Wear 200(1-2) (1996) 336-345. https://doi.org/10.1016/S0043-1648(96)07268-7.

[51] J.E. Fernández Rico, A. Hernández Battez, D. García Cuervo, Wear prevention characteristics of binary oil mixtures, Wear 253 (2002) 827-831. https://doi.org/10.1016/S0043-1648(02)00229-6.

[52] A. Cambiella, J.M. Benito, C. Pazos, J. Coca, A. Hernández, J.E. Fernández, Formulation of emulsifiable cutting fluids and extreme pressure behaviour, J. Mater. Process. Technol. 184 (2007) 139-145. https://doi.org/10.1016/i.jmatprotec.2006.11.014.

[53] M. Cai, Y. Liang, M. Yao, Y. Xia, F. Zhou, W. Liu, Imidazolium ionic liquids as antiwear and antioxidant additive in poly(ethylene glycol) for steel/steel contacts, ACS Appl Mater Interfaces 2 (2010) 870-876. https://doi.org/doi:10.1021/am900847j. 
1 [54] A.E. Jiménez, M.D. Bermúdez, Short alkyl chain imidazolium ionic liquid additives in lubrication of three aluminium alloys with synthetic ester oil, Tribol - Mater Surfaces Interfaces, 6 (2012) 109-15. https://doi.org/10.1179/1751584X12Y.0000000011.

[55] V. Pejaković, M. Kronberger, M. Kalin, Influence of temperature on tribological behaviour of ionic liquids as lubricants and lubricant additives, Lubr Sci $26 \quad$ (2014) 107-115. https://doi.org/doi:10.1002/ls.1233.

[56] A. H. Battez, D. Ramos, D. Blanco, R. González, A. Fernández-González, J. L. Viesca, Lubrication properties of the Ionic Liquid Dodecyl -3 Methylimidazolium bis (trifluoromethylsulfonyl)imide, Tribology Letters 66 (2018) 1-13. https://doi.org/10.1007/s11249$\underline{017-0964-Z}$.

[57] J.L. Viesca, M.T. Mallada, D. Blanco, A. Fernández-González, J. Espina-Casado, R. González, A. Hernández Battez, Lubrication performance of an ammonium cation-based ionic liquid used as an additive in a polar oil, Tribology International, 116(7) (2017), 422-430. https://doi.org/10.1016/j.triboint.2017.08.004.

[58] M. Kronberger, F. Pagano, V. Pejaković, A.Igartua, E. Urbistondo, M. Kalin, Miscibility and tribological investigations of ionic liquids in biodegradable esters, Lubrication Science, 26 (2014) 463-487. https://doi.org/10.1002/ls

[59] V. Sharma, N. Dörr, A. Erdemir, P.B. Aswath, Antiwear Properties of Binary Ashless Blend of Phosphonium Ionic Liquids and Borate Esters in Partially Formulated Oil (No Zn). Tribology Letters, 67(2) (2019) 1-13. https://doi.org/10.1007/s11249-019-1152-0.

[60] M. Smiglak, A. Metlen, R.D. Rogers, Second evolution of ionic liquids: from solvents and separations to advanced materials - energetic, Acc. Chem. Res. 40(11) (2007) 1182-1192. https://doi.org/10.1021/ar7001304.

[61] S.P.F. Costa, A.M.O. Azevedo, P.CA. G. Pinto, M.L.M.F.S. Saraiva, Environmental impact of ionic liquids: recent advances in (eco)toxicology and (bio)degradability, Chem. Sus. Chem. 10(10) (2017) 2321-2347. https://doi.org/10.1002/cssc.201700261.

[62] P. Nagendramma, S. Kaul, Development of ecofriendly/biodegradable lubricants: an overview, Renew. Sustain. Energy Rev. 16 (2012) 764-774. https://doi.org/10.1016/j.rser.2011.09.002. 
[63] C.J. Reeves, S. Garvey, P.L. Menezes, M. Dietz, T.C. Jen, M.R. Lovell, Tribological performance of environmentally friendly ionic liquid lubricants, Am. Soc. Mech. Eng. Tribol. Div. TRIB. (2012) $355-$ 357. https://doi.org/10.1115/IJTC2012-61180.

[64] A. Wang, L. Chen, D. Jiang, H. Zeng, Z. Yan, Vegetable oil-based ionic liquid microemulsion biolubricants: effect of integrated surfactants, Ind. Crops Prod. 62 (2014) 515-521. https://doi.org/10.1016/j.indcrop.2014.09.031.

[65] A.Z. Syahir, N.W.M. Zulkifli, H.H. Masjuki, M.A. Kalam, A. Alabdulkarem, M. Gulzar, L.S. Khuong, M.H. Harith, A review on bio-based lubricants and their applications, J. Clean. Prod. 168 (2017) 9971016. https://doi.org/10.1016/j.jclepro.2017.09.106.

[66] N. Adawiyah, S. Hawatulaila, A. Aini, A. Vijaya, M. Ibrahim, M. Moniruzzaman, Synthesis, characterization, ecotoxicity and biodegradability evaluations of novel biocompatible surface active lauroyl sarcosinate ionic liquids, Chemosphere, $229 \quad$ (2019) 349-357. https://doi.org/10.1016/j.chemosphere.2019.05.026.

[67] D. Parmentier, S.J. Metz, M.C. Kroon, Tetraalkylammonium oleate and linoleate based ionic liquids: promising extractants for metal salts, Green Chem. 15(1) (2013) 205-209. https://doi.org/10.1039/C2GC36458A.

[68] M.A.A. Rocha, A. Van Den Bruinhorst, W. Schröer, B. Rathke, M.C. Kroon, Physicochemical properties of fatty acid based ionic liquids, J. Chem. Thermodyn. (2016). https://doi.org/10.1016/j.jct.2016.04.021.

[69] R. Gusain, S. Dhingra, O.P. Khatri, Fatty-acid-constituted halogen-free ionic liquids as renewable, environmentally friendly, and high-performance lubricant additives, Ind. Eng. Chem. Res. 55(4) (2016) 856-865. https://doi.org/10.1021/acs.iecr.5b03347.

[70] R. Gusain O.P. Khatri, Fatty acid ionic liquids as environmentally friendly lubricants for low friction and wear, RSC Adv. 6(5) (2016) 3462-3469. https://doi.org/10.1039/C5RA25001C.

[71] A. Mezzetta, L. Guazzelli, M. Seggiani, C.S. Pomelli, M. Puccini, C. Chiappe, A general environmentally friendly access to long chain fatty acid ionic liquids (LCFA-ILs), Green Chem. 19 (2017) 3103-3111. https://doi.org/10.1039/c7gc00830a.

[72] M. Fan, L. Ma, C. Zhang, Z. Wang, J. Ruan, M. Han, Y. Ren, C. Zhang, D. Yang, F. Zhou, W. Liu, Biobased green lubricants: physicochemical, tribological and toxicological properties of fatty acid ionic liquids, Trib. Trans. 61(2) (2017) 195-206. https://doi.org/10.1080/10402004.2017.1290856. 
1 [73] P.K. Khatri, M.S. Aathira, G.D. Thakre, S.L. Jain, Synthesis and tribological behavior of fatty acid constituted tetramethylguanidinium (TMG) ionic liquids for a steel/steel contact, Mater. Sc. Eng. C 91 (2018) 208-217. https://doi.org/10.1016/j.msec.2018.05.038.

[74] G. Zheng, T. Ding, Y. Huang, L. Zheng, T. Ren, Fatty acid based phosphite ionic liquids as multifunctional lubricant additives in mineral oil and refined vegetable oil, Tribol. Int. 123 (2018) 316-324. https://doi.org/10.1016/J.TRIBOINT.2018.03.028.

[75] D. Blanco, N. Rivera, P. Oulego, M. Díaz, R. González, A.H. Battez, Novel fatty acid anion-based ionic liquids : Contact angle, surface tension, polarity fraction and spreading parameter, J. Mol. Liq. 288 (2019) 110995. https://doi.org/10.1016/j.molliq.2019.110995.

[76] N. Rivera, D. Blanco, J.L. Viesca, A. Fernández-González, R. González, A.H. Battez, Tribological performance of three fatty acid anion-based ionic liquids (FAILs) used as lubricant additive. J. of Mol. Liq. 296 (2019) 111881. https://doi.org/10.1016/j.molliq.2019.111881.

[77] A. Khan, R. Gusain, M. Sahai, O.P. Khatri, Fatty acids-derived protic ionic liquids as lubricant additive to synthetic lube base oil for enhancement of tribological properties, J. Mol. Liq. 293 (2019) 111444. https://doi.org/10.1016/J.MOLLIQ.2019.111444.

[78] N. Rivera, A. García, A. Fernández-González, D. Blanco, R. González, A.H. Battez, Tribological behavior of three fatty acid ionic liquids in the lubrication of different material pairs. J. Mol. Liq. 296 (2019) 111881. https://doi.org/10.1016/j.molliq.2019.111858.

[79] K. Ali, R. Moshikur, R. Wakabayashi, Y. Tahara, Synthesis and characterization of choline - fattyacid-based ionic liquids: A new biocompatible surfactant. Journal of Colloid and Interface Science, 551 (2019) 72-80. https://doi.org/10.1016/j.jcis.2019.04.095.

[80] P. Oulego, J. Faes, R. González, J.L. Viesca, D. Blanco, A.H. Battez, Relationships between the physical properties and biodegradability and bacteria toxicity of fatty acid-based ionic liquids. J. Mol. Liq., 292 (2019) 111451. https://doi.org/10.1016/j.molliq.2019.111451.

[81] T. Gundolf, N. Weyhing-Zerrer, J. Sommer, R. Kalb, D. Schoder, P. Rossmanith, P. Mester, Biological Impact of Ionic Liquids Based on Sustainable Fatty Acid Anions Examined with a Tripartite Test System, ACS Sustainable Chemistry and Engineering, 7(19) (2019) 15865-15873. https://doi.org/10.1021/acssuschemeng.8b06201. 
1 [82] R. Gusain, A. Khan, O.P. Khatri, Fatty acid-derived ionic liquids as renewable lubricant additives: Effect of chain length and unsaturation, Journal of Molecular Liquids, 301 (2020) 112322. https://doi.org/10.1016/j.molliq.2019.112322.

[83] M. Sernaglia, D. Blanco, A. Hernández Battez, J.L. Viesca, R. González, M. Bartolomé. Two fatty acid anion-based ionic liquids - part I: Physicochemical properties and tribological behavior as neat lubricants. Journal of Molecular Liquids

112827. 
Conflict of Interest and Authorship Conformation Form

Please check the following as appropriate:

$\mathrm{x} \quad$ All authors have participated in (a) conception and design, or analysis and interpretation of the data; (b) drafting the article or revising it critically for important intellectual content; and (c) approval of the final version.

$\mathrm{x}$ This manuscript has not been submitted to, nor is under review at, another journal or other publishing venue.

$\mathrm{x}$ The authors have no affiliation with any organization with a direct or indirect financial interest in the subject matter discussed in the manuscript. 


\section{Author Statement}

M. Sernaglia: Investigation, Writing- original draft; D. Blanco: Conceptualization, Investigation, Data curation, Writing-review and editing, Resources; A. Hernández Battez: Conceptualization, Methodology, Writing-review and editing, Project administration, Funding acquisition; A. Fernández-González: Investigation, Data curation; R. González:

Project administration, Funding acquisition, Supervision; M. Bartolomé: Data curation, Supervision. 


\section{SUPPLEMENTARY INFORMATION}

Table 1. Density and viscosity of the different base oils.

\begin{tabular}{lcccc}
\hline \multicolumn{1}{c}{ Base Oils } & $\begin{array}{c}\text { Density at } 15^{\circ} \mathrm{C} \\
\left(\mathrm{g} \cdot \mathrm{cm}^{-3}\right)\end{array}$ & $\begin{array}{c}\text { Kin. Viscosity } \\
\left(\mathrm{mm}^{2} \cdot \mathrm{s}^{-1}\right)\end{array}$ & Viscosity Index \\
\cline { 3 - 4 } & 0.9417 & 20.5 & 4.54 & 140 \\
\hline PRIOLUBE 3970 (POE) & 0.8750 & 32.0 & 5.20 & 98 \\
SN-150 & 0.8193 & 17.8 & 3.99 & 124 \\
PAO 4 & & ${ }^{\circ} \mathrm{C}$ & \\
\hline
\end{tabular}

Table 2. Density values of the FAIL-containing mixtures at different temperatures.

\begin{tabular}{cccccccccc}
\hline \multirow{2}{*}{ Samples } & \multicolumn{10}{c}{ Density $\left(\mathrm{g} . \mathrm{cm}^{-3}\right)$} \\
\cline { 2 - 9 } & $20{ }^{\circ} \mathrm{C}$ & $30^{\circ} \mathrm{C}$ & $40{ }^{\circ} \mathrm{C}$ & $50{ }^{\circ} \mathrm{C}$ & $60{ }^{\circ} \mathrm{C}$ & $70{ }^{\circ} \mathrm{C}$ & $80{ }^{\circ} \mathrm{C}$ & $90{ }^{\circ} \mathrm{C}$ & $100{ }^{\circ} \mathrm{C}$ \\
\hline POE + 0.5\% IL1 & 0.9417 & 0.9344 & 0.9272 & 0.9201 & 0.9109 & 0.9058 & 0.8987 & 0.8916 & 0.8846 \\
POE + 2.0\% IL1 & 0.9412 & 0.9340 & 0.9268 & 0.9196 & 0.9125 & 0.9054 & 0.8983 & 0.8913 & 0.8842 \\
POE + 0.5\% IL2 & 0.9411 & 0.9338 & 0.9266 & 0.9195 & 0.9124 & 0.9052 & 0.8981 & 0.8911 & 0.8840 \\
POE + 2.0\% IL2 & 0.9407 & 0.9335 & 0.9263 & 0.9192 & 0.9120 & 0.9050 & 0.8979 & 0.8908 & 0.8837 \\
\hline
\end{tabular}

Table 3. Kinematic viscosity of the FAIL-containing mixtures at different temperatures.

\begin{tabular}{cccccccccc}
\hline \multirow{2}{*}{ Samples } & \multicolumn{7}{c}{ Kinematic viscosity $\left(\mathrm{mm}^{2} . \mathrm{s}^{-1}\right)$} \\
\cline { 2 - 9 } & $20{ }^{\circ} \mathrm{C}$ & $30{ }^{\circ} \mathrm{C}$ & $40{ }^{\circ} \mathrm{C}$ & $50{ }^{\circ} \mathrm{C}$ & $60{ }^{\circ} \mathrm{C}$ & $70{ }^{\circ} \mathrm{C}$ & $80{ }^{\circ} \mathrm{C}$ & $90{ }^{\circ} \mathrm{C}$ & $100{ }^{\circ} \mathrm{C}$ \\
\hline POE + 0.5\% IL1 & 45.34 & 29.66 & 20.33 & 14.64 & 10.92 & 8.44 & 6.70 & 5.46 & 4.52 \\
POE + 2.0\% IL1 & 48.16 & 31.26 & 21.31 & 15.28 & 11.35 & 8.74 & 6.92 & 5.61 & 4.63 \\
POE + 0.5\% IL2 & 45.34 & 29.70 & 20.36 & 14.66 & 10.93 & 8.45 & 6.71 & 5.46 & 4.52 \\
POE + 2.0\% IL2 & 47.72 & 31.05 & 21.19 & 15.21 & 11.31 & 8.72 & 6.91 & 5.60 & 4.63 \\
\hline
\end{tabular}





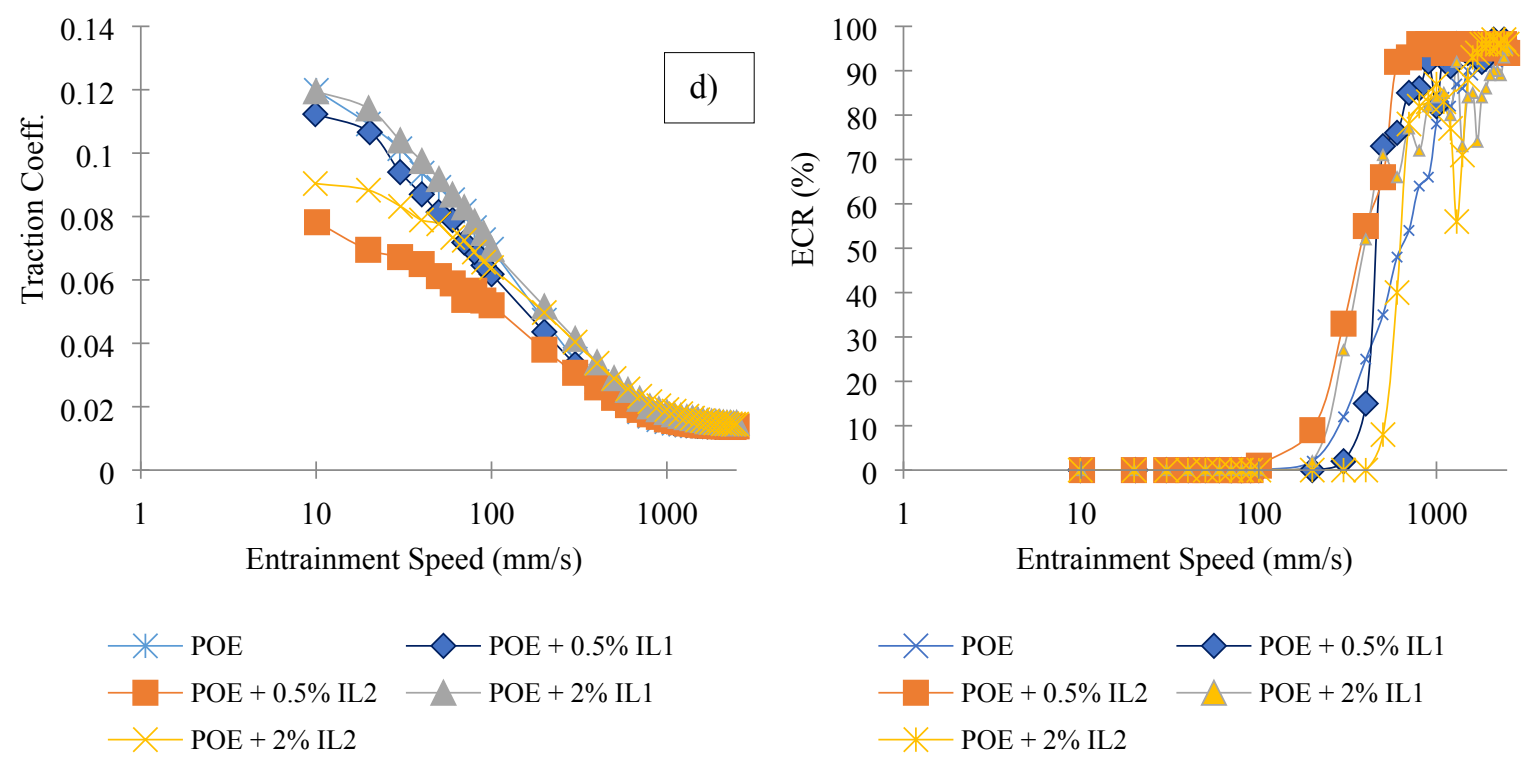

Fig. 1 Traction coefficient and electrical contact resistance (ECR) behavior versus speed for the pure base oil (polyol ester) and the base oil plus ionic liquids (IL1: $\left[\mathrm{N}_{6,6,6,6}\right]\left[\mathrm{C}_{8: 0}\right]$, IL2:

$\left.\left[\mathrm{N}_{6,6,6,6,6}\right]\left[\mathrm{C}_{16: 0}\right]\right)$ at the temperature of: a) $40{ }^{\circ} \mathrm{C}$; b) $60^{\circ} \mathrm{C}$; c) $80{ }^{\circ} \mathrm{C}$; d) $100^{\circ} \mathrm{C}$. 